\title{
INTEGRATED CURRICULUM MANAGEMENT IN FORMING STUDENTS 'LIFE SKILLS IN SDI QUR'ANI AL- BAHJAH TULUNGAGUNG
}

\author{
Nani Zahrotul Mufidah \\ Universitas Islam Zainul Hasan Genggong Probolinggo \\ nanizahrotul88@gmail.com
}

\begin{abstract}
Curculum management is one of the important things in achieving the content vision and goals of an institution. In this institution, an integrated curriculum management is used to create a generation of Qur'ani who have special skills to carry on life in the future, of course with the foundation of the institution as tahfidzul Qur'an and have other abilities according to the talents and interests of students. The way to achieve institutional goals is to do habituation and training through grouping according to the initial character of students. This is not to change the basic character, but to develop the potential or basic character that students have in order to be optimal. So when you leave the institution, you have at least 2 special abilities, namely in the field of tahfidzul Qur'an and also in the areas of interest and talents of each student.
\end{abstract}

Keyword: integrated curriculum, life skills, SDIQur'ani Al-Bahjah

\begin{abstract}
Abstrak
Manajemen kurkulum menjadi salah satu hal yang penting untuk mencapai visi isi dan tujuan dari sebuah lembaga. Pada lembaga ini menggnakan maajemen kurikulum terintegrasi untuk mewujudkan generasi Qur'ani yang memiliki skill khusus untuk melangsungkan kehidupan dimasa yang akan datang, tentu dengan basic dari lembaga sebagai tahfidzul Qur'an dan memiliki kemampuan lain sesuai dengan bakat dan minat peserta didik. Cara pencapaian tujuan lembaga adalah dengan melakukan pembiasaan dan penggemlengan melalui pengelompokan sesuai dengan karakter awal peserta didik. Disini bukan untuk merubah karakter dasar, akan tetapi mengembangkan potensi atau karakter dasar yang telah dimiliki oleh pesrta didik agar dapat optimal. Jadi begitu keluar dari lembaga minimal mempunyai 2 kemampuan sekligus, yakni dibidang tahfidzul Qur'an dan juga di bidang minat dan bakat dari masing-masing peserta didik.
\end{abstract}

Kata kunci: kurikulum terintegrasi, life skill, SDIQur'ani Al-Bahjah

Program Studi Pendidikan Guru Madrasah Ibtidaiyah

STAI Al-Azhar Menganti Gresik, Indonesia

\section{Pendahuluan}

Manajemen lembaga pendidikan Islam hendaknya perlu dilakukan penataan kembali supaya lebih bermakna baik secara demokratis, kreatif, efektif, dan efisien, memberikan keuntungan baik bagi stakeholders, komponen sekolah, maupun peserta didiknya. Begitu juga dengan fungsi pendidikan supaya tidak hanya menjalnkan tugas rutin mengajar, akan tetapi lebih dari itu fungsinya adalah untuk memberikan bekal kemampuan pada peserta didik untuk mewujudkan educated man yang mempunyai life skill yang berkualitas tinggi. Pengelolaan pendidikan Islam ini dilakukan diberbagai jenjang, jalur, lembaga formasl maupun non formal, dari jenjang Madrasah Ibtidaiyah, Madrasah Tsanawitah, Madrasah Aliyah hingga Pendidikan Tinggi. Pendidikan Islam merupakan usaha dari manusia untuk 
ZAHRA: Research And Tought Elmentary School Of Islam Journal Vol. (2) (2), (Agustus)(2021), (Halaman)(83-98)|

mengubah tingkah laku manusia dalam kehidupan pribadinya sebagai upaya memajukan dan memandirikan dirinya sesuai dengan nilai-nilai Islam supaya dapat menjalani kehidupan bermasyarakat dengan baik. Ilmu pendidikan secara teoritis dan praktis harus meningkatkan makna pengajaran, dan pemeliharaan menjadi pemberadaban. Dibutuhkan landasan yang kuat dan kokoh dalam mengembangkan sebuah pembelajaran pada dunia pendidikan Islam. Menjaga, memelihara, memperbaiki dan mengembangkan kualitas diri pribadi merupakan kunci dalam kurikulum terintegrasi. Pada dasarnya pendidikan yang ideal adalah pendidikan yang dapat memadukan antara kurikulum dengan kebutuhan yang ada. Dalam hal ini manajemen kurikulum terpadu haruslah mempunyai tiga aspek antara lain: pertama: pendidikan pribadi yang meliputi pendidikan tauhid kepada Allah dan nilai akidah, kedua: mengedepankan prinsip dan kejujuran dalam segala situasi, dan ketiga: pendidikan sosial masyarakat (Ulil, 2014). Kurikulum menjadi motor penggerak dalam proses pembelajaran, tidak hanya itu, kurikulum ini Juga perlu dipahami dan disadari oleh para pendidik sehingga hasil yang diperoleh aka menjadi maksimal, terutama bagi peserta didik. Banyak sekali konsep kurikulum yang mulai digagas oleh pemerintah maupun penggiat pendidikan. Perkembangan kurikulum yang digagas oleh pemerintah itu dapat dilihat dari mulai kurikulum 1994, CBSA, 2004, KBK, KTSP, dan kurikulum 2013. Ketika sebuah lembaga itu bergandengan dengan dunia pesantren maupun lembaga keagamaan juga akan melahirkan konsep kurikulum lain selain dari kurikulum yang telah didesain oleh pemerintah. Misalkan saja kurikulum berbasis pesantren, kurikulum berbasis keagamaan, kurikulum berbasis AlQur'an, kurikulum terintegrasi, dan sebagainya.

Sedangkan kurikulum terintegrasi merupakan kurikulum yang memungkinkan peserta didik baik secara individu, keseluruhan maupun kelompok bersikap aktif dalam menggali dan menemukan konsep dan prinsip-prinsip secara holistik, bermakna dan otentik, melalui pertimbangan itu maka berbagai pandangan dan pendapat tentang pembelajaran terintegrasi, tapi semuanya menekankan pada menyampaikan pelajaran yang bermakna dengan melibatkan siswa dalam proses pembelajaran. Melalui pembelajaran terintegrasi diharapkan para siswa memperoleh pengetahuan secara menyeluruh dengan cara mengaitkan satu pelajaran dengan pelajaran yang lain. Integrasi sendiri berasal dari kata "integer" yang berarti unit. Dengan integrasi dimaksud perpaduan, koordinasi, harmoni, kebulatan keseluruhan (Nasution, 2008). Hal tersebut terkait dengan kemajuan ilmu pengetahuan dan teknologi yang didorong oleh semangat memperluas berbagai aspek pendidikan yang dimotivasi oleh spirit Al-Qur'an. Al-Qur'an diturunkan kepada Nabi Muhammad SAW berabad-abad silam dengan 
sebuah awalan perintah untuk membaca (iqra') yang dalam konteks luas menjadi seruan untuk membaca, mengkaji, menganalisis, dan meneliti fenomena diri dan sekitar yang dalam aplikasi turunannya di kemudian hari telah melahirkan sebuah masyarakat berpendidikan dan menghasilkan sebuah karakter peradaban Islami yang kemudian menjadi titik tolak peradaban Barat yang kini menghegemoni arah sejarah peradaban manusia masa kini. Salah satu kemukjizatan sekaligus keunikan kitab suci Umat Islam yaitu Al-Qur'an adalah dapt dihafal seutuhnya oleh jutaan umat manusia sepanjang masa. Baik oleh anak-anak belia, remaja, dewasa hingga yang sudah lanjut usia (Abu Amar, 2015). Dari sinilah agenda besar tergambar jelas di depan mata yaitu untuk mengulang kembali kesuksesan Al-Qur'an sebagai kitab suci umat Islam yang telah menjadi tonggak inspirasi sebuah perubahan besar umat manusia dan sebagai pedoman dalam segala hal untuk mneyelesaikan masaah-masalah yang dihadapi, serta menjadikan kehidupan manusia menjadi lebih baik.

Tujuan utama pendidikan adalah untuk menyiapkan generasi bangsa supaya siap untuk menghadapi permasalahan pada kehidupannya kelak, untuk itulah peserta didik membutuhkan pendidikan kecakapan hidup atau life skill. Pendidikan kecakapan hidup ini sangat luas dan berangkat dari berbagai macam aspek kehidupan peserta didik, misalkan saja entrepreneurship, kemandirian hidup, kemampuan mengenal diri, kesadaran diri, kemampuan berfikir rasional, maupun keterampilan kejuruan. Pendidikan kecakapan hidup ini haruslah ditanamkan sejak dini. Zaman sudah berubah, kita tidak bisa lagi mendidik anak-anak kita dijaman sekarang dengan cara yang sama dengan orang tua dulu mendidik kita. Kita harus kreatif dan inovatif dalam mendidik anak dijaman sekarang. Anak-anak harus di ajarkan spirit entrepreneur sejak dini. agar kelak generasi penerus kita tidak lagi menjadi bangsa kuli karena hanya mengandalkan lapangan pekerjaan dari orang lain. Anak-anak dalam usia emas memiliki potensi luar biasa, terutama kerja otaknya. Pembentukan pribadi yang kuat dan tangguh serta pantang menyerah tentu harus menjadi catatan tersendiri pada proses pembelajaran. Pembentukan dan juga Penanaman jiwa berwirausaha dalam proses pembelajaran diharapkan menjadi salah satu proses untuk membentuk mental yang tangguh bagi peserta didik, sehingga ketika mereka dewasa mampu survive dan menciptakan lapangan kerja baru tanpa menggantungkan menjadi pegawai dan sebagainya. Dengan kecakapan yang mereka miliki tersebut akan sangat membantu ketika terjadi hal yang tidak diinginkan, misalkan sebuah perusahaan yang harus mengurangi jumlah karyawan karena kepentingan perusahaan atau PHK tidak menyebabkan mereka putus asa dan menjadi pengangguran. 
ZAHRA: Research And Tought Elmentary School Of Islam Journal Vol. (2) (2), (Agustus)(2021), (Halaman)(83-98)|

Senada dengan pemaparan tersebut juga ada artikel yang terkait yakni dimuat pada kompas Permasalahan yang berkembang sekarang adalah meskipun pemerintah telah membuat peraturan wajib belajar, pemberian beasiswa tetapi kurangnya adanya perhatian pemerintah tentang pentingnya pendidikan kecakapan hidup ( life skill education) khususnya bagi lulusan sekolah menengah umum (SMU). (Kompasiana, 2015).

Menurut penulis dari fenomena yang dipaparkan diatas tidak salah jika pendidikan kecakapan hidup itu penting untuk diterapkan sejak dini, mengapa menjadi penting? Karena pada usia ini merupakan usia emas untuk membentuk mindset peserta didik supaya tidak terpaku untuk menggantungkan sesuatu pada orang lain, meskipun pada dasarnya manusia merupakan makhluk sosial yang membutuhkan orang lain dalam interkasinya, namun bukan berarti menggantungkan sesuatu pada orang lain, akan lebih baik jika peserta didik yang sudah dibekali oleh kecapakan hidup tersebut mampu untuk menciptakan lapangan pekerjaan baru sehingga mampu untuk mengurangi tingkat pengangguran di Negara kita khususnya, dan memperbaiki perekonomian Negara.

Pada pembahasan ini penulis mendalami mengenai bagaimana pengintegrasian antara kurikulum dengan Al-Qur'an di dalam pembelajaran pada lembaga-lembaga pendidikan dasar, baik pada lembaga naungan kementrian pendidikan, maupun pada lembaga di bawah naungan kementrian agama. Sekarang ini mulai banyak bermunculan sekolah maupun madrasah yang menggunakan kurikulum yang diintegrasikan dengan Al-Qur'an. Seperti juga yang diterapkan pada dua lembaga yang coba dilihat lebih jauh oleh penulis, yaitu pada SDIQU Al-Bahjah Tulungagung.

Hasil survey awal di SDIQU Al-Bahjah Tulungagung yang merupakan salah satu lembaga pendidikan yang mulai berkembang, yang dirintis oleh Buya Yahya, menurut sumbernya SDIQU ini bermula dari lembaga tahfidz non formal yang didirikan untuk mencetak generasi-generasi penerus bangsa yang multi talent, artinya mereka dididik untuk menjadi pendakwah yang hafidz dan memahami Al-Qur'an secara mendalam. Melihat fenomena sekarang ini yang menurut pendiri sudah mulai kehilangan tongkat penyangga kehidupan, moral mulai hilang, persaudaraan sesama mulai hilang, karakter mulai hilang, banyak budaya asing yang tidak sesuai justru dikonsumsi dan dijadikan patokan hidup, sedangkan semakin kesini pada da'i dan ulama sepuh sudah banyak yang kembali keharibaan sang pencipta, sehingga membuat kehidupan para penerus akan rusak jika para penerus bangsa tidak berpedoman pada Al-Qur'an. 
Setelah pondok tahfidz berjalan banyak para wali santri yang mengusulkan untuk dibuka sekolah formal, supaya selain menjadi hafidz juga bisa memperdalam ilmu umum sebagai bekal kehidupannya di masa mendatang. Barulah mulai dibuka SDIQU tersebut. SDIQU sendiri singkatan dari Sekolah Dasar Islam Qur'ani, yang mempunyai kurikulum utama berbasis Al-Qur'an. Meskipun menggunakan kurikulum baik dari kemenag maupun kemendiknas akan tetapi pada SDIQU ini mempunyai kurikulum sendiri yang wajib untuk didikuti oleh masing-masing peserta didik. Pada lembaga SDIQU ini juga terdapat program boarding school sehingga pada tataran pembentukan kecakapan hidup akan dibentuk selama 24 jam di asrama baik untuk santri banin maupun banat. Memang sejatinya tidak semua anak akan memiliki kemampuan akhir yang sama, akan tetapi di asrama itulah peserta didik mempunyai perlakuan yang sama dalam segala hal. Mulai dari pembiasaan-pembiasaan dalam mencapai target hafalan al-Qur'an hingga membentuk bakat yang dimiliki untuk dikembangkan menjadi kecakapan hidup mereka.

Ada sistem yang telah ditata oleh pengelola lembaga untuk sebisa mungkin memaksimalkan kemampuan dasar peserta didik yang ditemukan oleh penulis ketika melakukan survey awal pada lembaga SDIQU Al-Bahjah, antara lain: pembentukan skill entrepreneurship dengan membiasakan anak untuk tidak takut untuk memulai sesuatu, ada pelatihan keterampilan untuk berwirausaha seperti berdagang (terdapat kantin yang dikelola oleh santri), belajar untuk menjadi pendakwah yang mempunyai pengetahuan yang luas. Membentuk kemandirian peserta didik dengan tinggal di asrama, jauh dari orang tua, berusaha menjaga diri sendiri, mengurus segala keperluan diri sendiri, mengikuti semua peraturan yang ada di asrama, melatih kemampuan untuk menghafal dan memahami makna al-Qur'an, dan mempunyai tanggung jawab terhadap diri sendiri untuk melakukan segala sesuatu. Menjalin komunikasi dengan masyarakat, melalui program pelatihan, pengajian rutin di asrama, asrama dibangun di lingkungan sekitar yang mendukung program lembaga, mengadakan pertemuan rutin dengan masayarakat sekitar, kerja bakti secara rutin, ikut membantu kegiatan yang diselenggarakan di sekitar asrama. Hasil survey yang dilakukan oleh peneliti menemukan beberapa bagian pengelolaan pendidikan yang didalamnya memuat pendidikan kecakapan hidup, sehingga peneliti tidak mengada-adakan masalah yang akan diteliti, hanya saja untuk mengetahui dan menjelaskan sejauh mana keefektifan dan hasil dari program yang ada pada lembaga pendidikan tersebut peneliti perlu untuk melakukan penelitian ini lebih mendalam lagi. Demi pencapaian tujuan lembaga yang ideal dan maksimal pada lembaga yang telah dipaparkan tersebut di atas, maka penulis akan 
ZAHRA: Research And Tought Elmentary School Of Islam Journal Vol. (2) (2), (Agustus)(2021), (Halaman)(83-98)|

menjelaskan dan membahas lebih mendalam mengenai "Manajemen Kurikulum terintergasi dalam membentuk Life Skill Peserta didik" dengan lokasi di SDIQU Al-Bahjah Tulungagung. Hal tersebut menurut peneliti penting untuk dilakukan, karena pada dasarnya pendidikan haruslah mampu untuk menyiapkan peserta didik untuk menghadapi tantangan zaman yang akan dihadapi pada kehidupannya kelak, hal tersebut juga diungkapkan dalam salah satu artikel yang ditulis oleh Mislaini yang menyatakan bahwa kecakapan hidup haruslah ditumbuhkan dalam diri masing-masing peserta didik guna untuk membersamai mereka ketika sudah terjun di masyarakat, saat mereka terjun menjadi bagain dari masyarakat yang haruslah mampu untuk berfikir dan bertindak secara dewasa, kritis, berakhlak dalam menyikapi kehidupan, dapat memberi kontribusi positif serta tetap survive di tengah-tengah kehidupan pada zamannya (Mislaini, 2017).

Pada hakikatnya pengembangan kecakapan hidup pada peserta didik haruslah mampu untuk mengaktifkan dan menggerakkan semua nilai positif yang ada pada diri peserta didik, supaya dapat memiliki kompetensi yang berkembang secara maskimal, dan dapat diterapkan dalam kehidupan sehari-hari peserta didik itu sendiri. Selama ini pendidikan dan pengembangan kecakapan hidup masih ssering diabaikan dan lebih cenderung pada prestasi akademik saja. Maka dari itu penulis berusaha untuk menggali apa yang ada di lembaga tersebut dalam upaya untuk mengembangkan potensi dan life skill peserta didik.

\section{A. Manajemen Kurikulum Pendidikan Islam}

Manajemen kurikulum itu berasal dari dua kata yaitu manajemen dan kurikulum, yang kedua-duanya memiliki pengertian yang berbeda. Manajemen secara bahasa berasal dari kata to manage yang berarti mengelola. Pengelolaan dilakukan melalui proses dan dikelola berdasarkan urutan dan fungsi-fungsi manajemen itu sendiri. Manajemen adalah melakukan pengelolaan sumber daya yang di miliki oleh sekolah atau organisasi yang di antaranya adalah manusia, uang, metode, material, mesin dan pemasaran yang dilakukan dengan sistematis dalam suatu proses (Oemar Hamalik, 2007). Manajemen adalah proses merencana, mengorganisasi, memimpin dan mengendalikan upaya organisasi dengan segala aspeknya agar tujuan organisasi tercapai secara efektif dan efisien. Manajemen diartikan sebagai ilmu, kiat, dan profesi (Nanang Fattah, 2009). Kurikulum adalah seperangkat rencana dan pengaturan mengenai tujuan, isi, dan bahan pelajaran serta cara yang digunakan sebagai pedoman penyelenggaraan kegiatan pembelajaran untuk mencapai tujuan pendidikan tertentu. Manajemen kurikulum adalah suatu sistem 
pengelolaan kurikulum yang kooperatif, komprehensif, sistemik, dan sitematik dalam rangka mewujudkan ketercapaian tujuan kurikulum (Rusman, 2009).

Manajemen kurikulum merupakan rangkaian perangkat kemampuan dalam mengelola kurikulum, mulai dari perencanaan kurikulum hingga evaluasi kurikulum. Kurikulum yang baik adalah kurikulum yang mengikuti perkembangan ilmu dan teknologi yang berbasis pada masyarakat. Kegagalan dalam memanaje sebuah kurikulum akan berakibat fatal pada keberhasilan dunia pendidikan. Oleh karena itu, setiap penanggungjawab lembaga pendidikan dan seluruh stakeholder pendidikan harus memiliki visi yang sama dalam merencanakan, mengorganisasi, melaksanakan, dan mengevaluasi sebuah kurikulum. (Ibrahim Nasbi, 2017).

\section{B. Kurikulum Sekolah Terintegrasi Al-Qur'an}

Kurikulum sekolah terintegrasi Al-Qur'an merupakan salah satu rancangan kurikulum yang didesain untuk mencetak generasi yang tidak hanya memberikan ilmu pengetahuan dan teknologi tetapi juga memiliki program unggulan yaitu Tahfidzul Qur'an (program menghafal Al-Qur'an). Konsep kurikulum sekolah terintegrasi AlQur'an disini dengan memasyarakatkan tahfidzul qur'an melalui lembaga-lembaga tahfidz, pendirian rumah-rumah tahfidz, ataau menghidupkan halaqoh tahfidz, baik dari majlis, masjid hingga melalui lembaga pendidikan formal (Abu Ammar, 2015). Kurikulum terintegrasi yang dimaksud adalah dengan memadukan antara beberapa kurikulum baik kurikulum nasional dengan kurikulum lokal sesuai dengan visi misi dan tujuan lembaga.

Melalui pembelajaran terpadu, peserta didik dapat memperoleh pengalaman langsung sehingga dapat menambah kekuatan untuk menerima, menyimpan, dan menerapkan konsep yang telah dipelajarinya. Peserta didik dilatih untuk dapa menemukan sendiri berbagai konsep yang dipelajari secara menyeluruh (holistis), bermakna, autentik, aktif. Pengalaman belajar yang lebih menunjukkan kaitan unsure-unsur konseptual akan menjadikan proses belajar lebih efektif. (Kompasiana, 2015)

\section{Life Skill Peserta didik}

Peserta didik merupakan sumber daya utama dan terpenting dalam proses pendidikan. Peserta didik bisa belajar tanpa guru. Sebaliknya, guru tidak bisa mengajar tanpa peserta didik. Karenanya kehadiran peserta didik menjadi keniscayaan dalam proses pendidikan formal atau pendidikan yang dilambangkan dengan menuntut interaksi antara pendidik dan peserta didik (Sudarwan Danim, 2010). Kemampuan awal (Entry Behavior) adalah kemampuan yang telah diperoleh siswa sebelum dia memperoleh kemampuan 
terminal tertentu yang baru. Kemampuan awal menunjukkan status pengetahuan dan keterampilan siswa sekarang untuk menuju ke status yang akan datang yang diinginkan guru agar tercapai oleh siswa. Dengan kemampuan ini dapat ditentukan dari mana pengajaran harus dimulai. Kemampuan terminal merupakan arah tujuan pengajaran diakhiri. Jadi, pengajaran berlangsung dari kemampuan awal sampai ke kemampuan terminal itulah yang menjadi tanggung jawab pengajar (Mukhtar 2003). Secara kodrati, manusia memiliki potensi dasar yang secara esensial membedakan manusia dengan hewan, yaitu pikiran, perasaan, dan kehendak. Sekalipun demikian, potensi dasar yang dimilikinya itu tidaklah sama bagi masing-masing manusia (Sunarto dan Agung Hartono, 2008).

Rendahnya kualitas pendidikan di Indonesia dibanding Negara lain di dunia menjadikan Indonesia sulit mengejar kemajuan seperti negara-negara tetangga. Berdasarkan Human Development Index (HDI) Indonesia berada di urutan 102 dari 106 Negara, Political Economic Risk Consultant (PERC) Indonesia berada di urutan 12 dari 12 Negara, satu peringkat dibawah Vietnam. Tingginya peserta didik yang tidak melanjutkan ke Jenjang yang lebih tinggi terjadi di semua Jenjang. (SD 19,3 \% ke SLTP 34,40 \% ke SLTA 53,12 \% ke PT). Rendahnya daya tampung PT 12,6 \%, 88,4 \% masuk dunia kerja tanpa memiliki bekal kecakapan Hidup (Life Skill) Problem utama yang dihadapi dunia pendidikan saat ini masih berkisar pada personal dan persoalan mutu, efisiensi, dan relevansi. (Nindya Yuliwulandana, 2).

Terdapat keunikan-keunikan yang ada pada diri manusia. Pertama, manusia berbeda dengan makhluk lain, seperti binatang ataupun tumbuhan. Perbedaan tersebut karena kondisi psikologisnya. Kedua, baik secara fisiologis maupun psikologis manusia bukanlah makhluk yang statis, akan tetapi makhluk yang dinamis, makhluk yang mengalami perkembangan dan perubahan. Ia berkembang khususnya secara fisik dari mulai ketidakmampuan dan kelemahan yang dalam segala aspek kehidupannya membutuhkan bantuan orang lain, secara perlahan berkembang menjadi manusia yang mandiri. Ketiga, dalam setiap perkembangannya manusia memiliki karakter yang berbeda (Wina Sanjaya, 2011).

Secara umum pendidikan kecakapan hidup bertujuan untuk memfungsikan pendidiakan sesuai dengan fitrahnya, yaitu mengembangkan potensi manusiawi peserta didik untuk menghadapi perannya di masa datang. Secara khusus pendidikan yang berorientasi pada kecakapan hidup (life skill) bertujuan untuk: 
1. Mengaktualisasikan potensi peserta didik sehingga dapat digunakan untuk memecahkan problema yang dihadapi.

2. Merancang pendidikan agar fungsional bagi kehidupan peserta didik dalam menghadapi kehidupan di masa datang.

3. Memberikan kesempatan kepada sekolah untuk mengembangkan pembelajaran yang fleksibel, sesuai dengan prinsip pendidikan berbasis luas.

4. Mengoptimalkan pemanfaatan sumber daya di lingkungan sekolah, dengan memberi peluang pemanfaatan sumber daya yang ada di masyarakat, sesuai dengan prinsip manajemen berbasis sekolah. (Depdiknas, 2001).

Namun demikian, kenyataan menunjukkan bahwa sekolah hanya dapat memberi pelajaran secara teori dan kurang memberikan keterampilan sebagai bekal hidup dan pembinaan mental. Untuk itu, perlu dilakukan suatu usaha untuk mengembalikan peran sekolah sebagai penyelenggara pendidikan untuk menolong individu, keluarga, masyarakat dan negara dalam menjawab permasalahan yang perlu dipecahkan.

\section{Metode Penelitian}

Penelitian ini Mendeskkripsikan data yang dikumpulkan bersifat deskriptif atau kata-kata, maka penelitian ini termasuk dalam kategori penelitian kualitatif. Penelitian kualitatif adalah penelitian yang bermaksud untuk memahami fenomena tentang apa yang dialami oleh subjek penelitian misalnya, perilaku, persepsi, motivasi, tindakan, dll. Secara holistik, dan dengan cara deskripsi dalam bentuk kata-kata dan bahasa, pada suatu konteks khusus yang alamiah dan dengan memenfaatkan berbagai metode alamiah. Dalam penelitian ini ada tiga tahap dalam pengumpulan data yaitu:

\section{A. Observasi}

Observasi Partisipatif : observasi adalah teknik pengumpulan data yang dilakukan melalui suatu pengamatan, dengan disertai pencatatan-pencatatan terhadap keadaan suatu perilaku objek sasaran. Observasi adalah teknik pengamatan yang dilakukan seorang peneliti dalam memperoleh bahan-bahan atau data yang dilakukan dengan mengadakan pengamatan dan mendengarkan secermat mungkin baik itu yang dikerjakan orang, mendengarkan apa yang mereka ucapkan dan berpartisipasi dalam aktivitas mereka. Dalam hal ini yang dilakukan oleh peneliti adalah melihat dan mengamati apa saja kejadian yang ada di lapangan terkait dengan pengembangan kurikulum terintegrasi dalam membentuk skill dan juga pengalaman belajar peserta didik ketika proses pembelajaran. Meliputi kegiatan pengamatan proses kegiatan pembelajaran tahfidz, pelatihan ekstrakurikuler, pembelajaran kurikulum 2013, maupun kegiatan halaqoh serta pelatihan skill peserta didik yang ada di lembaga pendidikan Islam Al-Bahjah. 


\section{B. Wawancara}

Wawancara adalah percakapan dengan maksud tertentu. Percakapan itu dilakukan oleh dua pihak, yaitu pewawancaraan yang mengajukan pertanyaan dan terwawancara yang memberikan jawaban atas pertanyaan itu. Hal tersebut bertujuan untuk memperoleh informasi kepada kepala sekolah, guru mata pelajaran, guru pendamping, maupun peserta didik. Kegiatan wawancara dilakukan dengan menggunakan pedoman wawancara yang ditekankan pada kondisi faktual yang sesuai dengan fokus penelitian yang telah dipaparkan diatas. Kegiatan wawancara ini dilakukan dengan beberapa tahap dan beberapa sumber, yakni wawancara dengan kepala tahfidz, wawancara dengan Pembina tahsin dan tahsili, wawanca tersebut berkaitan dengan alurdan pola pembelajaran tahfidz yang diadakan, mengingat pembelajaran tahfidz pada lembaga ini termasuk ke dalam pembelajaran inti dan masuk pada kurikulum sekolah. Kemudan wawancara juga dilakukan kepada kepala sekolah dan juga guru yang ada di masing-masing kelas baik guru tahfidz maupun guru kelas, terkait dengan pembagian jadwal dan juga pelajaran yang dilaksanakan sehari-hari.

\section{Dokumentasi}

Dokumentasi adalah metode yang digunakan untuk mencari data mengenai hal-hal atau variabel yang berupa catatan, transkip, buku, surat kabar, majalah, prasasti, notulen, rapat, agenda dan sebagainya. Dokumentasi didalam penelitian ini digunakan untuk melengkapi data-data yang diperoleh dari hasil observasi dan wawancara. Dokumen biasanya dibagi atas dokumen pribadi dan dokumen resmi. Sesuai dengan pandangan tersebut, peneliti mengguanakan metode dokumentasi sebagai alat pengumpul data dari sumber bahan tertulis yang terdiri dari dokumen resmi yang dimiliki lembaga pendidikan seperti arsip, dan dokumen tidak resmi, misalnya peneliti memotret ketika proses wawancara dilaksanakan.

\section{Hasil Penelitian}

Pengembangan kurikulum terus berjalan seiring dengan perkembangan zaman, tak dapat dipungkiri tuntutan kebutuhan mengharuskan kurikulum terus berkembang. Sebagaimana pemaparan pada bagian sebelumnya, bahwa kurikulum mempunyai banyak model dalam pengembangannya. Salah satunya adalah kurikulum terintegrasi atau integrated curriculum. Kurikulum ini adalah salah satu model kurikulum yang meleburkan antar materi pelajaran menjadi satu kesatuan, materi - materi pelajaran tersebut di bagi ke dalam unit - unit tema yang sesuai, sehingga penyampaian materi tak lagi terbatas mata pelajaran.

Kurikulum terintegrasi ini banyak pula jenisnya, biasanya pengintegrasian kurikulum ini disesuaikan dengan visi misi dan tujuan lembaga pedidikan yang dikelola. Salah satu pengembangan kurikulum terintegrasi yang sedang ramai dibicarakan adalah kurikulum qur'an terintegrasi. Pengembangan kurikulum tersebut muncul bukan tanpa dasar, melainkan akibat fenomena yang ada sekarang ini. Banyak permasalahan yang timbul seiring dengan perkembangan zaman, antara lain: krisis moral, kasus korupsi yag merajalela, kejahatan semakin banyak, pengangguran, nyawa manusia 
ZAHRA: Research And Tought Elmentary School Of Islam Journal Vol. (2) (2), (Agustus)(2021), (Halaman)(83-98)|

tak lagi berharga, banyak kasus pembunuhan karena hal sepele, bahkan nalar tak lagi berfungsi. Beberapa masalah tersebut disinyalir akan terus mengganas jika generasi penerus tidak segera diberikan pondasi yang kuat sehingga mampu menghadapi permasalahan hidup yang sedang atau akan dihadapi kelak.

Pada lembaga ini peneliti menemukan program pengintegrasian kurikulum yang berbeda dengan lembaga kebanyakan, yakni pengembanagan kurikulum terintegrasi al-Qur'an, lembaga memberikan alasan jika saat ini pemahaman masyarakat terkait al-Qur'an ketika diaplikasikan dalam kehidupan sehari-hari sudah mulai hilang, sehingga lembaga yang juga dibawah naungan pondok pesantren Al-Bahjah yang dikembangkan oleh Buya Yahya ini mengusung tema khusus dengan mengedaepankan pemahaman makna al-Qur'an dalam kehidupan sehari-hari para santri dan juga peserta didiknya. Lembaga ini sengaja membuat pengembangan kurikulum yang berbeda, di sini pengembangan kurikulum diintegrasikan dengan pendidikan al-Qur'an karena ingin mengembalikan pemaknaan al-Qur'an dalam kehidupan sehari-hari. Semua pembelajaran dan pengetahuan didasarakn pada al-Qur'an dan al-Hadits supaya nantinya pemaknaan mereka dapat menyeluruh dan tidak melenceng dari tuntunan al-Qur'an. Meskipun begitu pasti selalu ada pro dan kontra dengan apa yang diterapakan oleh lembaga satu ini. Namun disini para pengelola tidak terlalu mempermasalahkan hal tersebut selama tidak mengggu prose pembelajaran maupun merusak apa yang menjadi tujuan awal dari lembaga ini, yakni membumikan al-Qur'an dan pembentukan skill dari peserta didik.

Dari hasil observasi dan wawancara dengan beberapa sumber yang dilakukan oleh peneliti, pada lembaga ini ada jam khusus untuk program tahfidz yang menjadi salah satu unggulan yang ada pada lembaga ini. Pada program tahfidz untuk tingkah sekolah dasar difokuskan pada 10 juzz, yakni juzz 30, kemudian juzz 29 lalu juzz 1 hingga juzz 8, yang menjadi ciri khusus lainnya adalah terkait metode yang digunakan pada lembaga ini, mereka para ustadz dan ustadzah tahfidz menggunakan metode tallaqi dan juga metode tahsin tahshili yang menjadi ciri khas dari Al-Bahjah. Menurut kepala tahfidz kenapa pada program tahfidz dilakukan dengan terbalik, karena mereka berusaha untuk membuat nyaman para peserta didik yang akan memulai untuk menghafal dan belajar memaknai alQur'an dari yang mudah menuju yang sulit. Karena menurut mereka basic dari program ini selain untuk menghafal al-qur'an juga untuk memaknai dan memahami ayat-ayatnya supaya bisa diterapkan dan dijadikan tauladan dalam kehidupan sehari-hari mereka.

Selanjutnya adalah terkait dengan perkembangan dan pertumbuhan peserta didik ketika menggunakan kurikulum yang ada tentu tidak mudah, karena pada dasranya setiap peserta didik mempunyai karakter yang berbeda. Pada aspek pembentukan karakter dan pengembangan life skill peserta didik pada lembaga ini mengacu pada beberapa aspek yakni:

1. Perkembangan berlangsung seumur hidup dan meliputi seluruh aspek.

2. Setiap individu mempunyai kecepatan dan kualitas perkembangan yang berbeda - beda.

3. Perkembangan secara relative beraturan, mengikuti pola - pola tertentu. 
ZAHRA: Research And Tought Elmentary School Of Islam Journal Vol. (2) (2), (Agustus)(2021), (Halaman)(83-98)|

4. Perkembangan berlangsur secara berangsur - angsur sedikit demi sedikit.

5. Perkembangan berlangsung dari kemampuan yang bersifat umum menuju ke yang lebih khusus, mengikuti proses difensiasi dan integrasi.

6. Secara normal perkembangan individu mengikuti seluruh fase, tetapi karena faktor - faktor khusus, fase tertentu dilewati dengan cepat atau sangat lambat.

7. Sampai pada batas - batas tertentu perkembangan suatu aspek dapat dipercepat maupun diperlambat. Perkembangan diperngaruhi oleh faktor pembawaan maupun faktor lingkungan.

8. Perkembangan aspek tertentu berjalan sejajar atau berkorelasi dengan aspek yang lainnya.

9. Pada saat - saat tertentu dan dalam bidang tertentu perkembangan pria berbeda dengan perkembangan wanita.

Ada banyak faktor yang mempengaruhi perkembangan dari peserta didik sebagaimana disebutkan diatas, akan tetapi dalam menyikapi karakter masing-masing peserta didik masing-masing lembaga mempunyai cara yang berbeda, salah satunya dengan membentuk cluster-cluster sesuai dengan kemampuan dan juga minat dari peserta didik, sehingga nanti nya proses pembentukan skill menjadi lebih efektif. Pada lembaga ini ada beberapa jenis pelatihan skill untuk peserta didik, antara lain dibidang dakwah, berbisnis, maupun menjadi pendidik, selain yang utama menjadi Hafidz Qur'an dengan memaknai secara benar. Pada hasil temuan dari lembaga ini ada beberapa pembagian kelompok yang menjadi basic dari pengelolaan lembaga, yaitu:

1. Pembagian kelas berdasarkan kemampuan tahfidz, jadi sering ditemukan kelas umum belum tentu sama dengan kelas tahfidz, dari sini akan diketahui sejauh mana kemampuan dan kecepatan hafalan al-Qur'an

2. Pembagian jam pelajaran sekolah yang berbeda, karena pelajaran tahfidz masuk pada jam pelajaran formal, tujuannya adalah membiasakan peserta didik untuk mempelajari dan mendalami kandungan ayat-ayat al-Qur'an sebagai bekal kehidupannya kelak.

3. Ada beberapa pilihan untuk mengetahui minat dan bakat peserta didik melalui jaring bakat, jadi tidak melulu menghafal al-Qur'an akan tetapi juga menggali bakat dan minat peserta didik melalui ekstrakurikuler dan juga jajag minat peserta didik, sehingga para ustdaz ustadzah lebih mudah dalam membimbing dan mengarahkan bakat peserta didik

4. Ada pengajian wali santri atau halaqoh yang didalamnya membahas secara menyeluruh tentang metode pembelajaran tahfidz yakni tahsin dan tashili, sehingga mempermudah wali santri untuk mendampingi peserta didik ketika menghafal al-Qur'an.

5. Diajarkan mandiri sejak dini melalui program boarding school dan melatih skill peserta didik untuk menyalurkan bakat dan minat peserta didik, contohnya apabila ada yang suka berdagang difasilitasi kantin yang dikelola oleh peserta didik, untuk yang suka berceramah ada akelas untuk belajar bersama para asatidz, diajari cara bersosialisasi dengan masyarakat sekitar dengan mengadakan kunjungan dan pengajian bersama. 
Namun demikian pada tingkat dasar tentu pengembangan bakat dan minat peserta didik belum sepenuhnya dapat berkembang, akan tetapi tujuan utama lembaga adalah untuk membangun pondasi yang kuat pada tiap peserta didik bahwa kemandirian dan kemampuan individu itu sangat penting untuk menjalani kehidupan peserta didik di masa yang akan datang, bahkan setelah mereka keluar dari lembaga ini akan menjadi awal dari perjuangan menghadapi kehdupan yang sebenarnya, akan bertemu dengan orang-orang yang tidak semuanya baik dan seperti yang mereka inginkan, pasti ada saja yang tidak senang dan berusaha menjatuhkan mereka.

Fungsi dari pembentukan skill pada lembaga ini lebih pada penyiapan diri peserta didik untuk siap meghadapi segala tantangan baik yang bersifat positif maupun negative dengan kemampuan awal yang telah dimiliki oleh pesrta didik, karena pada dasrnya setiap eserta didik akan mempunyai karakter yang berbeda-beda meskipun dapat dikelompokan menjadi kelompok yang komplek. Pada lembaga ini ada beberapa langkah mereka untuk membentuk skill dari peserta didik, antara lain dengan membentuk wadah semacam ekstrakurikuler yang didalamnya ada beberapa pilihan sesuai dengan bakat dari masing-masing peserta didik, misalkan: Hadrah, didalamnya mempelajari segala macam alat music hadrah dan rebana, juga latihan vocal untuk mengasah kemampuan peserta didik. Ada juga kitab kuning, yang dikhususkan pada santri atau peserta didik yang ingin melanjutkan pendidikannya di jalur khusus ataupun belajar di luar negeri. Ada juga kantin dan koperasi yang diperuntukkan untuk santri dan juga peserta didik untuk melatih jiwa berwirausaha mereka.

Meskipun pengembangan tetap terfokus pada program tahfidz dan pemaknaan al-Qur'an sebagai bekal para peserta didik nantinya, akan tetapi lembaga ini masih selalu konsisten untuk menjaga dan eksis dalam pengembangan dakwah dalam bentuk apapun, terkait dengan syiar dan juga pengembangan kepribadian peserta didik. Banyak pro kontra dalam lingkup masyarakat sekitar tentu bukan menjadi halangan yang besar bagi mereka karna prinsip dari lembaga adalah mendakwahkan dan membumikan al-Qur'an sebagai pedoman hidup dan menjawab tantangan zaman dengan segala permasalahannya melalui al-Qur'an dan al-Hadits sebagai sumbernya.

\section{Diskusi}

Mengidentifikasi kemampuan awal dan karakteristik siswa dalam pengembangan program pembelajaran sangat perlu dilakukan, yaitu untuk mengetahui kualitas perseorangan sehingga dapat dijadikan petunjuk dalam mendeskripsikan strategi pengelolaan pembelajaran. Aspek-aspek yang diungkap dalam kegiatan ini bisa berupa bakat, motivasi belajar, gaya belajar kemampuan berfikir, bakat, minat dan lain sebagainya. Hasil kegiatan mengidentifikasi kemampuan awal dan karakteristik siswa akan merupakan salah satu dasar dalam mengembangkan sistem instruksional yang sesuai untuk peserta didik. Dengan melaksanakan kegiatan tersebut, masalah heterogen siswa dalam kelas dapat diatasi, setidak-tidaknya dapat meminimalisir keterogenan peserta didik. Dalam pengembangan skill peserta didik juga akan sangat membantu sebagaimana pengelompokan yang diadakan di lembaga SDI Al-Bahjah ini. Seski tidak bisa teroganisir 100\% akan tetapi dengan mengelompokkan peserta 
ZAHRA: Research And Tought Elmentary School Of Islam Journal Vol. (2) (2), (Agustus)(2021), (Halaman)(83-98)|

didik sesuai dengan bakat dan kemampuan awal akan mampu memaksimalkan pembentukan karakter maupun skill dari masing-masing peserta didik.

Dalam Undang Undang Sistem pendidikan Nasional Republik Indonesia No. 20 tahun 2003 tentang Sistem Pendidikan Nasional pasal 26 ayat 3 menyatakan bahwa "pendidikan kecakapan hidup (life skill) adalah pendidikan yang memberikan kecakapan personal, kecakapan sosial, kecakapan intelektual, dan kecakapan vokasional untuk bekerja atau usaha mandiri. Dari pengertian di atas, dapat diartikan bahwa pendidikan kecakapan hidup merupakan pendidikan kecakapan-kecakapan yang secara praktis dapat membekali peserta didik dalam mengatasi berbagai macam persoalan hidup dan kehidupan. Pada lembaga ini sudah mulai dibentuk dan dikelola dengan membagi beberapa aspek dalam membentuk skill peserta didik dengan adanya wadah-adah pengembangan bakat dan minat peserta didik, sehingga mampu untuk menghasilkan generasi yang berlandaskan al-Qur'an dan alHadits sebagai pedoaman hidup. Namun demikian pembentukan skill ini tidak langsung dapat terlihat karena semua akan membutuhkan proses yang lebih lama lagi, pada intinya salah satu keunikan lembaga ini adalah dengan mempersempt heterogenitas peserta didik untuk mengembangkan karakter dan skill sesuai dengan kemampuan awal dari peserta didik. Semoga kedepannya akan lebih banyak lagi pengembangan yang dilakukan sehingga jangkauan juga semakin luas.

\section{Simpulan}

Adapun simulant dari penelitian ini adalah manajemen kurikulum itu sangat penting dalam sebuah lembaga pendidikan apalagi di tingkat dasar, karena pada fase ini peserta didik berada pada fase operasional konkrit yang mengharuskan lembaga mempunyai contoh - contoh atau fakta-fakta yang dapat dijadikan sebagai pedoman dan tolak ukur untuk mengembangakan skill peserta didik kedepannya. Namun pengembangan skill ini tentu tidak bisa berjalan maksimal, karena pada tahap ini tentu pembentukan skill merupakan pengenalan awal pada peserta didik bahwa nantinya setelah dewasa akan mengalami berbagai permasalahan yang harus dihadapi, sehingga peserta didik harus mempunyai kemampuan yang unggul dari dalam diri peserta didik sesuai dengan kemampuan, bakat dan juga minat dari peserta didik itu sendiri, sedangkan fungsi lembaga adalah menjembatani dan memberikan fasilitas yang mampu untuk menunjang kemampuan dasar dari peserta didik itu sendiri. Tentu saja hasil akhir dari lulusan akan berbeda antara satu dengan yang lainnya. Hal ini membuktikan bahwa masing-masing peserta didik itu mempunyai karakter yang berbeda antara satu dengan yang lainnya.

\section{Daftar Pustaka}

Ammar, Abu \& Abu Fatiah Al-Adnani. (2015). Negeri-Negeri Penghafal Al-Qur'an: Inspirasi dan Motivasi Semarak Tahfidz Al-Qur'an dari 32 Negara di 4 Benua. Solo: Al-Wafi, cetakan I.

Danim, Sudarwan. (2010). Perkembangan Peserta Didik. Bandung: Alfabeta.

Dirjen Dikdasmen Depdiknas. (2001). "Peserta didik Lebih Memilih Life Skill." http://www.Depdiknas.go.id. 
ZAHRA: Research And Tought Elmentary School Of Islam Journal Vol. (2) (2), (Agustus)(2021), (Halaman)(83-98)|

Fathoni, Abdurrahman. (2006). Metodologi Penelitian \& Teknik Penelitian Sekripsi. Jakarta: Rineka Cipta.

Fattah, Nanang. (2009). Landasan manajemen pendidikan. Bandung: Remaja rosdakarya.

Hamalik, Oemar. (2007). Manajemen Pengembangan Kurikulum. Bandung: Remaja Rosdakarya.

Kompasiana. (2015). "Pentingnya Pendidikan Kecakapan Hidup." https://www.kompasiana.com/netytabelak/552a66926ea8349045552d38/pentingnyapendidika n-kecakapan-hidup.

Mislaini. (2017). "Pendidikan dan Bimbingan Kecakapan Hidup (Life Skill) Peserta didik Tarbawiyah." Jurnal Ilmiah Pendidikan, Vol.1, No.1, p-ISSN: 2579-3241; e-ISSN: 2579$325 \mathrm{Xd}$.

Mukhtar. (2003). Desain Pembelajaran Pendidikan Agama Islam. Cet 1. Jakarta: CV Misaka Galiza.

Nasbi, Ibrahim. (2017). "MANAJEMEN KURIKULUM: Sebuah Kajian Teoritis.” JURNAL IDAARAH, $\quad$ Vol.1, No.2, $\quad$ http://journal.uinalauddin.ac.id/index.php/idaarah/article/viewFile/4274/3936.

Nasution, S. (2008). Asas-Asas Kurikulum. Jakarta: Bumi Aksara.

Sanjaya, Wina. (2011). Perkembangan dan Desain Sistem Pembelajaran. Jakarta: Kencana Prenada Media Group.

Sukmadinata, Nana Syaodih. (2004). Landasan Psikologi Proses Pendidikan. Bandung: PT Remaja Rosdakarya.

Sunarto \& Agung Hartono. (2008). Perkembangan Peserta Didik. Jakarta: Rineka Cipta.

Syafri, Ulil Amri. (2014). Pendidikan Karakter Berbasis Al-Qur'an. Jakarta: Rajawali Pers.

Yuliwulandana, Nindya. "PENGEMBANGAN MUATAN KECAKAPAN HIDUP (LIFE SKILL) PADA PEMBELAJARAN DI SEKOLAH.” https://core.ac.uk/download/pdf/235260265.pdf. 